REPORTS OF MORPHOLOGY
Official Journal of the Scientific Society of Anatomists,
Histologists, Embryologists and Topographic Anatomists
of Ukraine
journal homepage: https://morphology-journal.com

\title{
The vaginal bacterial dysbiosis severity predicting model according to the normobiota index
}

\section{Hruzevskiy O.A. ${ }^{1}$, Minukhin V.V. ${ }^{2}$}

${ }^{1}$ Odessa National Medical University, Odessa, Ukraine

${ }^{2}$ I.I.Mechnikov Institute of Microbiology and Immunology of National Academy of Medical Sciences of Ukraine, Kharkiv, Ukraine

\section{ARTICLE INFO}

Received: 23 June, 2020

Accepted: 24 July, 2020

UDC: $618.15-002: 616-093-/ 098$

\section{CORRESPONDING AUTHOR}

e-mail: gruzevskiy@ua.fm Hruzevskyi O.A.

\begin{abstract}
The local and systemic immunodeficiency is the main mechanism for vaginal bacterial dysbiosis and its extreme manifestation - bacterial vaginosis (BV) development. The complex immune response study and the establishment of the main mechanisms and factors, reflecting it and corresponding to the microbiocenosis severity disorder are relevant. Aim - to develop a neural network model of the severity of vaginal bacterial dysbiosis based on the assessment of normobiota. Divided into the following groups according to the Conditionally pathogenic microflora index (CPMI) and normobiota index (NBI): normocenosis ( $n=53)$, dysbiosis I $(n=128)$ and II degree $(n=117)$ among the latter 83 patients with $P N B>1 \mathrm{lg}$ GE/sample were identified, in whom BV was established. Molecular genetic studies of the epithelium scraping from the vagina posterolateral wall were carried out by Polymerase chain reaction ("DNK-Technologiia" LLC, RF). Facultative and obligate anaerobes, myco- and ureplasmas, and yeast-like fungi were quantified. The content of immunoglobulins, lysozyme, cytokines, complement, phagocytosis activity of leukocytes, hormones, the number of lymphocytes and their fractions, as well as the vaginal discharge $\mathrm{pH}$ (a total of 58 indexes) were identified in blood and vaginal discharge. For statistical and mathematical analysis, the Statistica 10 software (StatSoft, Inc., USA) was used. Using neural network modeling, it was revealed that among all the factorial signs for determining the bacterial dysbiosis degree, the complement component C4 and $y$-INF content in the vaginal discharge and circulating immune complexes (CIC) and $T N F \alpha$ in the blood were important. A linear neural network model was built on the selected set of factor signs (the Cohen's kappa coefficient consent index on the training set was $\kappa=0.87$ (95\% Cl 0.82-0.91)), for confirming plurality $-\kappa=0.89(95 \% \mathrm{Cl} 0.77-1.00)$. With normocenosis, the complement activation PNB was decreased, and $\gamma$-INF and TNFa content was increased. The CIC levels blood increase corresponded to the opportunistic microflora growth and reflected the humoral immune response activation, which suggests that this indicator is an early dysbiosis marker. With I degree dysbiosis all factors had positive relationship with NBI, which reflected the immune system stress state. In case of II degree dysbiosis, NBI had a negative relationship with $\gamma$-INF content in the vaginal discharge, and CIC in the blood, while positive - with $\mathrm{C}_{4}$ content in vaginal discharge, and TNFo in the blood, which proved the immune system dysregulation and caused its further suppression with the BV-association immunodeficiency development. The immune system reaction during the BV development evolved from non-specific resistance reactions to cytokine-induced reactions of specific humoral immunity in response to the $B V$-associated microbiota growth, which subsequently experienced depletion and loss of immune control.

Keywords: bacterial vaginosis, normobiota index, immune system.
\end{abstract}

\section{Introduction}

Vaginal bacterial dysbiosis is a nonspecific infectious non-inflammatory syndrome in which the content of obligate- and facultative-anaerobic opportunistic pathogens increases in vaginal discharge with a decrease in the content or complete absence of normobiota (Lactobacillus spp.) [1, 12, 22]. The extreme severity of dysbiosis is bacterial vaginosis (BV), which causes inflammation of the pelvic organs, and during pregnancy 
causes the threat of pregnancy, premature birth and postpartum infections of mother and child [19, 21]. BV has been shown to contribute to the incidence of HIV [16] and papillomavirus infection, as well as associated with cervical cancer [2].

The causes of BV are disruption of the vaginal ecosystem due to suppression of natural defense mechanisms - vaginal microbiocenosis, the formation of colonial resistance factors, as well as local nonspecific immune defense (phagocytosis reactions and complement activation, etc.) $[3,18]$. Activated by molecular microbial pathogens, macrophages of the vaginal mucosa through the formation of proinflammatory cytokines [15] trigger cellular and humoral immune responses [11]. At the same time, against the background of BV and an increase in the absolute number of BV-associated pathogens (Gardnerella vaginalis, Mycoplasma hominis, etc.) there is a decrease in systemic and local inflammatory response, local and systemic immunodeficiency [4].

The main mechanism of $\mathrm{BV}$ development is local immunodeficiency and reduction of colonization resistance of vaginal discharge $[3,18]$, but, in addition to local, systemic immunodeficiency is also formed [5]. Antigen-presenting cells of the vagina, primarily macrophages and dendritic cells, are activated by bacterial antigens, release proinflammatory cytokines and involve cellular and humoral links in the immune response [11]. Decreased systemic and local inflammatory response correlates with the degree of bacterial dysbiosis [17].

Thus, a comprehensive study of the local and local immune response, as well as the establishment of the main mechanisms of BV development and the factors that reflect them, seems relevant.

The aim of the study was to develop a neural network model of the severity of vaginal bacterial dysbiosis based on the assessment of normobiota.

\section{Materials and methods}

The study used data from 298 women between the ages of 16 and 64 who consulted a gynecologist for a preventive examination or for complaints of discomfort in the genital area. The exclusion criterion was the presence of unduly pathogenic microorganisms in the scrapings of the vaginal epithelium (Trichomonas vaginalis, Neisseria gonorrhoeae, Chlamydia trachomatis and Herpes Simplex Virus 1,2). The presence of more than 15-20 leukocytes in the field of view in vaginal smears, which indicated the presence of an inflammatory reaction, was also an exclusion criterion.

During the examination, a scraping of the epithelium was taken from the posterior lateral wall of the vagina using a urogenital probe. Molecular genetic studies were performed by polymerase chain reaction (PCR). DNA was isolated using a set of reagents "Proba-HS" ("DNA Technology", Russia). Amplification of test tubes with the reaction mixture was performed in the amplifier "DTLite"
("DNA Technology", Russia). To study the state of the vaginal biocenosis, we used the "Femoflor 16" test system, which is designed for real-time PCR. The microbiota was quantified by the following indicators [14]: total bacterial mass (TBM), normobiota (Lactobacillus spp.), Obligate anaerobes (Lactobacillus spp.), облігатні анаероби (Atopobium vaginalis, Eubacterium spp., Gardnerella vaginalis, Prevotella bivia, Porphyromonas spp., Lachnobacterium spp., Clostridium spp., Megasphaera spp., Veilonella spp., Dialister spp., Mobiluncus spp., Corynebacterium spp., Peptostreptococ spp., Sneathia spp., Leptotrihia spp., Fusobacterium spp.), facultative anaerobes (Enterobacteriaceae spp., Staphylococcus spp., Streptococcus spp.), Mycoplasma and ureaplasma (Ureaplasma urealiticum + parvum, Mycoplasma hominis + genitalium) and yeast-like fungi (Candida spp.).

The criterion for dividing patients into groups was conditionally pathogenic microflora index (CPMI), which was calculated as the difference between the sum of all opportunistic pathogens and the number of lactobacilli (in Ig GE/sample). In the normocenosis CPMI was lower than -3 lg GE/sample (1 group; $n=53$ ), in dysbiosis of the first degree CPMI was in the range from -3 to $-1 \mathrm{lg}$ GE/sample

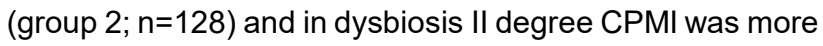
than -1 lg GE/sample (group 3; n=117) [9]. Groups with dysbiosis were divided into subgroups according to the normobiota index (NBI), which was calculated as the difference between the total bacterial mass (TBM) and the number of lactobacilli (in Ig GE/sample). In group 2 there are three subgroups: 1 - with $\mathrm{NBI} \leq 0$, Ig GE/sample $(n=23)$, 2 - with $\mathrm{NBI}$ from 0.3 to $1.0 \mathrm{lg} \mathrm{GE} /$ sample $(n=83)$ and 3 with $\mathrm{NBI}>1$ Ig GE/sample ( $\mathrm{n}=22$ ). In group 3 , two subgroups were distinguished: 1 - with $\mathrm{NBI} \leq 1 \lg \mathrm{GE} /$ sample $(\mathrm{n}=34)$ and 2 - with $\mathrm{NBI}>1 \mathrm{lg} \mathrm{GE} /$ sample $(\mathrm{n}=83)$. In the last subgroup, the degree of dysbiosis was maximal and corresponded to the state of BV [8].

According to standard immunological methods [5, 20], the content of immunoglobulins $A(\lg A), M(\lg M)$ and $G(\lg G)$ in blood serum and vaginal discharge was determined ("Granum" test systems, Ukraine); the content of immunoglobulin $\mathrm{G}_{2}\left(\lg \mathrm{G}_{2}\right)$ and secretory $\lg \mathrm{A}(\mathrm{s} \lg \mathrm{A})$ ("Hema", Russia); the content of transforming growth factor $1 \beta$ (TGF$1 \beta$ ) (DRG, USA); immune complexes (IC, in vaginal discharge) and circulating IC (CIC, in blood) by their selective precipitation in a solution of polyethylene glycol; content of interleukins $1 \beta$ (IL1 $\beta$ ), 2 (IL2), 4 (IL4), 6 (IL6), 8 (IL8), 10 (IL10), tumor necrosis factor $\alpha$ (TNFa) and $\gamma$ interferon ( $\mathrm{\gamma}$-INF) ("Vector-Best", Russia); content of complement components C3 and C4 ("PLIVA-Lachema Diagnostica s.r.o", Czech Republic); lysozyme (DRG, USA). Determination of leukocyte phagocytic activity (PAL) was performed using a suspension of yeast cells ("Granum", Ukraine); PAL was calculated as the average number of particles absorbed by one active neutrophil per 100 cells, the PAL index (IPAL) was calculated as the percentage of phagocytes from the number of counted neutrophils. The 
Table 1. Factor features of the indicators primary analysis of vagina colonial resistance, immune system and hormonal regulation system.

\begin{tabular}{|c|c|c|c|c|c|}
\hline $\mathrm{X} 1$ & Age & $\mathrm{X} 20$ & IL10 & X39 & CD22+ \\
\hline X2 & $\begin{array}{c}\text { Day of } \\
\text { menstrual cycle }\end{array}$ & X21 & TNF $\alpha$ & $\times 40$ & PAL \\
\hline \multicolumn{2}{|c|}{ Indicators of VD: } & $\mathrm{X} 22$ & TGF-1 $\beta$ & X41 & $\mathrm{I}_{\mathrm{PAL}}$ \\
\hline X3 & $\operatorname{lgM}$ & $\mathrm{X} 23$ & $\mathrm{pH}$ & X42 & $\mathrm{ClC}$ \\
\hline $\mathrm{X} 4$ & $\lg A$ & \multicolumn{2}{|c|}{$\begin{array}{l}\text { Indicators in the } \\
\text { blood: }\end{array}$} & X33 & $\mathrm{C}_{3}$ \\
\hline$\times 5$ & $\lg G$ & X24 & $\mathrm{FSH}$ & X44 & $\mathrm{C}_{4}$ \\
\hline $\mathrm{X} 6$ & $\lg G 2$ & X25 & LH & X45 & $\gamma-$ INF \\
\hline $\mathrm{X} 7$ & slgA & $\mathrm{X} 26$ & E2 & $\mathrm{X} 46$ & IL1 $\beta$ \\
\hline X8 & Lysozyme & $\mathrm{X} 27$ & PG & X47 & IL2 \\
\hline $\mathrm{X} 9$ & PAL & $\mathrm{X} 28$ & TS & $\mathrm{X} 48$ & IL4 \\
\hline $\mathrm{X} 10$ & IPAL & X29 & CR & $\times 49$ & IL6 \\
\hline $\mathrm{X} 11$ & IC & X30 & PRL & $\times 50$ & IL8 \\
\hline $\mathrm{X} 12$ & $\mathrm{C}_{3}$ & X31 & $\mathrm{ft}_{3}$ & $\times 51$ & IL10 \\
\hline $\mathrm{X} 13$ & $\mathrm{C}_{4}$ & X32 & $\mathrm{ft}_{4}$ & X52 & TNF $\alpha$ \\
\hline $\mathrm{X} 14$ & $\gamma-\mathrm{INF}$ & X33 & Lc & X53 & TGF-1 $\beta$ \\
\hline X15 & IL1 $\beta$ & X34 & CD16+ & X54 & $\operatorname{lgM}$ \\
\hline $\mathrm{X} 16$ & IL2 & $\times 35$ & CD3+ & X55 & $\lg A$ \\
\hline X17 & IL4 & X36 & CD4+ & $\times 56$ & $\lg G$ \\
\hline $\mathrm{X} 18$ & IL6 & X37 & CD8+ & $\times 57$ & $\lg G 2$ \\
\hline $\mathrm{X} 19$ & IL8 & X38 & IPI & X58 & $\operatorname{slg} A$ \\
\hline
\end{tabular}

Notes: VD - vaginal discharge.

number of lymphocytes in the blood (Lc) was counted [20]; quantitative determination of CD3+, CD4+, CD8+, CD16+ and CD22+ cells was performed with the use of erythrocyte diagnosticums of "Granum" (Ukraine); calculated the immunoregulatory index (IRI) as the ratio of CD4+/CD8+. The $\mathrm{pH}$ of vaginal discharge was determined using test strips "Kolpo-Test pH" manufactured by "Biosensor AN" (RF). Enzyme-linked immunosorbent assay in the serum determined the content of hormones: luteotropic (LH), follicle-stimulating (FSH), prolactin (PRL), cortisol (CR), progesterone (PG), estradiol (E2), testosterone (TSC), free triiodothyronine (T3) and free thyroxine (T4) using reagent kits produced by "Granum" (Ukraine).

Arithmetic mean $(M)$ and mean error $(m)$ were used for descriptive data statistics. Paired independent data samples were compared according to the Mann-Whitney (U) test. The construction of prognostic models was performed using neural network modeling [10]. The method of genetic analysis was used to select the most significant factor traits. In all types of comparative statistical analysis, the significance of the differences was taken at $p<0.05$. The statistical software package Statistica 10 (StatSoft, Inc., USA) was used for statistical processing of the obtained data.

Prediction of the severity of dysbiosis by $\mathrm{NBI}$ was performed by neural network analysis, which used the results of examination of all 298 patients, 53 of whom were diagnosed with normocenosis, 128 dysbiosis of I degree and 117 - dysbiosis of II degree. At the beginning of the analysis, all the studied factors (58 indicators in total) were presented as factor features, which are shown in Table 1.

To check the quality of model prediction, all observations (using a random number generator) were divided into three sets: training (used to calculate model parameters, 248 cases), control (used to control model retraining, 20 cases), confirmatory (used to check adequacy models when forecasting on new data, 30 cases).

\section{Results}

A linear neural network model was built and trained on a complete set of 58 factor features (see Table 1). Cohen kappa agreement index for this model on a training set was $\kappa=0.99(95 \% \mathrm{Cl} 0.97-1.00)$, on the confirmatory set $\kappa=1.00(95 \% \mathrm{Cl} 0.99-1.00)$, which testified to the adequacy of the model that was built.

Significant traits were selected using a genetic algorithm method to identify the factors most associated with NBI. As a result, four factor traits were selected: levels in the vaginal discharge of the complement component $\mathrm{C} 4$ (X13) and $\mathrm{Y}$-INF (X14), as well as blood levels of CIC (X42) and TNFa (X52).

A linear neural network model was built and trained on a separate set of four factor features. Cohen kappa agreement index for this model on a training set was $\kappa=0.87$ $(95 \% \mathrm{Cl} 0.82-0.91)$, on the confirmatory set $\kappa=0.89(95 \%$ Cl $0.77-1.00)$, which testified to the adequacy of the constructed model.

Thus, the model for predicting the severity of dysbiosis for NBI, based on four factor traits, gave a "very good" $(\kappa>0.81)$ agreement, which indicated the high significance of the selected factor traits (content in the vaginal discharge of $\mathrm{C}_{4}$ and $\mathrm{y}$-INF, as well as the content in the blood of $\mathrm{CIC}$ and TNFa) to predict the severity of dysbiosis by NBI.

The constructed model can be expressed by a system of equations (1):

$\mathrm{V} 0=-0,101 \times \mathrm{X} 13-0,091 \times \mathrm{X} 14+0,001 \times \mathrm{X} 42-$

$0,031 \times \times 52+1,726$

$\mathrm{V} 1=0,092 \times \mathrm{X} 13-0,262 \times \times 14-0,010 \times \times 42+$

$0,019 \times \times 52-1,380$

$\mathrm{V} 2=0,009 \times \mathrm{X} 13-0,171 \times \mathrm{X} 14-0,012 \times \mathrm{X} 42+$

$0,012 \times \times 52+0,654$

where V0 corresponds to the diagnosis of "normocenosis", V1 corresponds to the diagnosis of "grade I dysbiosis", V2 corresponds to the diagnosis of "grade II dysbiosis"; the decision is made on the maximum value of the resulting indicator $\mathrm{V}$.

Changes in the content of selected by the results of neural network modeling of the immune system in dysbiosis of varying degrees are given in Table 2.

The content of the complement component $C_{4}$ in the vaginal discharge was increased compared to the norm 
Table 2. Indicators of the immune system, which were selected at a previous stage by the results of neural network modulation (M $\pm m$ ).

\begin{tabular}{|c|c|c|c|c|c|}
\hline \multirow{2}{*}{\multicolumn{2}{|c|}{ Group, subgroup }} & \multicolumn{2}{|c|}{ Content in VD } & \multicolumn{2}{|c|}{ Blood content } \\
\hline & & $\mathrm{C} 4, \mu \mathrm{g} / \mathrm{ml}$ & $\gamma-\mathrm{INF}, \mathrm{pg} / \mathrm{ml}$ & CIC, Ex.U. & $\mathrm{TNF} \alpha, \mathrm{pg} / \mathrm{ml}$ \\
\hline \multicolumn{2}{|l|}{1 (normocenosis), $n=53$} & $3.532 \pm 0.071$ & $1.871 \pm 0,061$ & $46.12 \pm 1,32$ & $14.64 \pm 0,46$ \\
\hline \multirow{3}{*}{2 (dysbiosis of the I degree), $n=128$} & $1, n=23$ & $3.642 \pm 0.111$ & $1.931 \pm 0.051$ & $44.33 \pm 2.41$ & $18.92 \pm 0.73^{*}$ \\
\hline & $2, n=83$ & $4.622 \pm 0.081^{*}$ & $2.472 \pm 0.041^{*}$ & $54.91 \pm 1.03^{*}$ & $31.89 \pm 0.59^{*}$ \\
\hline & $3, n=22$ & $2.281 \pm 0.071^{*}$ & $0.841 \pm 0.031^{*}$ & $33.63 \pm 1.12^{*}$ & $30.76 \pm 1.22^{*}$ \\
\hline \multirow{2}{*}{3 (dysbiosis of the II degree), $n=117$} & $1, n=34$ & $1.191 \pm 0.031^{*}$ & $0.711 \pm 0.021^{*}$ & $45.36 \pm 1.59$ & $31.29 \pm 0.87^{*}$ \\
\hline & $2, n=83$ & $0.601 \pm 0.011^{*}$ & $0.411 \pm 0.011^{*}$ & $25.23 \pm 0.39^{*}$ & $52.62 \pm 0.86^{*}$ \\
\hline
\end{tabular}

Notes: VD - vaginal discharge; * - probability of discrepancies using the Mann-Whitney U-test compared with the corresponding indicator in group $1(p<0.001)$.

for the normocenosis in grade I dysbiosis (2 subgroups in 1.3 times; $p<0.001$ ), decreased with the transition to grade II dysbiosis (up to $50-66 \%$ of the level of normocenosis) and decreased sharply on the background of BV (up to $17 \% ; p<0.001$ ). Earlier we showed $[6,7]$ that the content of immune complexes in vaginal discharge also decreased in grade II dysbiosis and the decrease in complement content was the reason for such a decrease in the formation of immune complexes on the background of $\mathrm{BV}$.

The content of $\gamma$-INF did not actually change in subgroup 1 in dysbiosis of the first degree, but reached a maximum in subgroup 2 (increased in 1.3 times; $p<0.001$ ). With the deepening of the level of dysbiosis, the content of $\mathrm{y}$-INF decreased and in BV and was $21.9 \%$ of normocinosis $(p<0.001)$. The level of complement changed similarly. $\mathrm{Y}$-IFN is an active proinflammatory factor that is associated with innate and adaptive immunity, along with other proinflammatory factors (such as IL1 $\beta$ and TNF $\alpha$ ), it activates T-lymphocytes and monocytes to activate the expression of the chemokine cascade [5]. Therefore, the activation of humoral immunity, a significant indicator of which according to the results of studies was the C4 component of complement and the content of $\mathrm{Y}$-IFN, which involves the cell, reflected in the dysbiosis of the first degree reaction to the local immune response. With the further development of dysbiosis, significant suppression of both indicators was noted.

Confirmation of the important regulatory role of $\mathrm{Y}$-IFN is its negative relationship with $\mathrm{NBI}$, detected during regression analysis ( $\beta$-regression coefficient was -0.28 ; $p<0.001)$ in grade I dysbiosis. The same signs of dependence were found in the phagocytic activity of leukocytes (IPAL) and the content of slgA, which indicates an active reaction of the nonspecific immune system to the factors of colonization resistance of vaginal discharge.

$\mathrm{CIC}$ contain antigens, antibodies and components of complement $\mathrm{C}_{3}, \mathrm{C}_{4}, \mathrm{C}_{1 \mathrm{q}}$ [5]. According to the results of regression analysis, in dysbiosis of the first degree in blood content, the $\mathrm{CIC}$ had a negative effect on $\mathrm{NBI}$ ( $\beta$-regression coefficient was $-0.138 ; p=0.027)$. Therefore, such data suggest that dysbiosis was a provoking factor for the

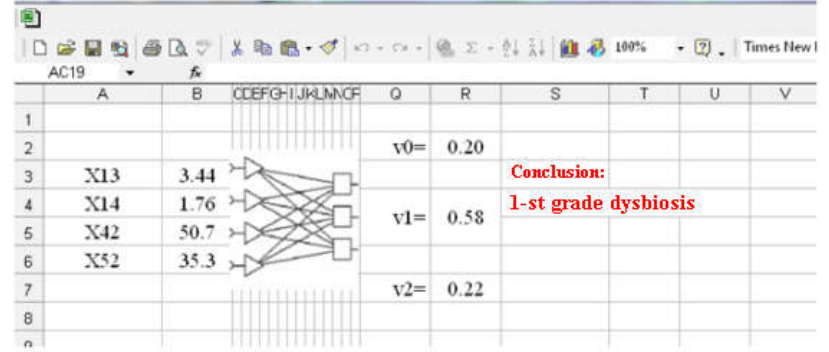

Fig. 1. The interface expert system predicting the severity of dysbiosis according to NBI.

activation of the humoral part of the immune system.

For the practical use of the model for predicting the severity of dysbiosis by NBI in the environment of the Excel spreadsheet implemented an expert system. Figure 1 shows its interface. To work in the program, you must enter the values of the indicators for a particular patient in the appropriate cells of the spreadsheet. The expert system will issue a forecast of the severity of dysbiosis according to NBI. From the three equations (V0, V1 and V2) the maximum value of the calculated NBI is chosen.

Thus, patient P., 40 years old, had the following indicators: levels in vaginal discharge $\mathrm{C}_{4}-3.44 \mu \mathrm{g} / \mathrm{ml}$ and $\mathrm{Y}$-INF - $1.94 \mathrm{pg} / \mathrm{ml}$; blood levels of CIC - 42.7 Ex.U. and TNFa - $13.8 \mathrm{pg} / \mathrm{ml}$. Predicted NBI - "Normocenosis", the actual value of NBI - 0.05; diagnosis: Normocenosis.

Patient P., 31 years old, had the following indicators: levels in vaginal discharge $\mathrm{C}_{4}-4.38 \mu \mathrm{g} / \mathrm{ml}$ and $\mathrm{V}$-INF $1.76 \mathrm{pg} / \mathrm{ml}$; blood levels of CIC - 50.7 Ex.U. and TNFa $35.3 \mathrm{pg} / \mathrm{ml}$. Predicted NBI - "Dysbiosis of the I degree"; the actual value of $\mathrm{NBI}-0.4$, diagnosis: Dysbiosis of the first degree (Fig. 1).

Patient S., 16 years old, had the following indicators: levels in vaginal discharge $\mathrm{C}_{4}-0.53 \mu \mathrm{g} / \mathrm{ml}$ and $\mathrm{y}-\mathrm{INF}-0.46 \mathrm{pg} / \mathrm{ml}$; blood levels of CIC - 23.9 Ex.U. and TNFa $-57.5 \mathrm{pg} / \mathrm{ml}$. Predicted NBI - "Dysbiosis of the II degree", the actual value of $\mathrm{NBI}$ - 4.6; diagnosis: Dysbiosis of the II degree.

\section{Discussion}

As we showed earlier $[6,7,8]$, in the process of development of vaginal dysbiosis there was a formation of 
a single pathological hormonal-immune system, which causes and supports the development of BV. Such a system included the formation of local and systemic immunodeficiency and a number of hormonal disorders. In this work, the task was to develop and analyze a mathematical model of the pathological process and determine the factors that determine the severity of dysbiosis. As a result, NBI was considered, which objectively reflected the degree of increase in pathogenic microflora and decrease in the number of lactobacilli $[8$, 14].

Analysis of the system of equations 1 showed some patterns of progression of dysbiosis. In the normocenosis (equation $\mathrm{V} 0$ ) the negative signs of the coefficients (ie those that reduced $\mathrm{NBI}$ ) had the content in the vaginal discharge of the complement component $\mathrm{C}_{4}, \mathrm{Y}$-INF and the content of TNFa in the blood, and positive (increased in parallel with $\mathrm{NBI}$ ) - the content in the blood CIC. In other words, in the normocenosis, the conditionally pathogenic microflora was directly controlled by the activation of complement $\left(\mathrm{C}_{4}\right)$ and the increase in the level of cytokines - $y-I N F$ and TNFa. The increase in the content of $\mathrm{CIC}$ in the blood reflected the parallel to the growth of opportunistic pathogenic microflora activation of the humoral immune response. Therefore, this state of the immune system can be characterized as controlled in relation to the development of vaginal dysbiosis, and the accumulation in the blood of $\mathrm{CIC}$ in the normocenosis can be recommended as an early marker of activation of opportunistic pathogens.

In grade I dysbiosis (equation $\mathrm{V} 1$ ), none of the coefficients had a negative sign of the coefficients, ie they all had a positive relationship, and therefore increased according to the increase in NBI. In other words, all significant factors responded to the activation of opportunistic pathogenic microflora, which, under such conditions, acquired the properties of an uncontrolled process that had the ability to self-sustain and progressive self-stimulation [8, 9]. In our opinion, the change of the sign of all coefficients to positive reflected the maximum stress of immune mechanisms with the progression of dysbiosis.

In grade II dysbiosis (equation V2), negative coefficients appeared for the content of $\mathrm{Y}-\mathrm{INF}$ in the vaginal discharge and the $\mathrm{CIC}$ content in the blood, and positive for the content of $\mathrm{C}_{4}$ in the vaginal discharge and TNFa in the blood. Therefore, we can assume that under conditions of developed vaginal dysbiosis, dysregulation of the immune system was formed, which changed the state of tension and preceded the pronounced suppression of reactions of both local and systemic immunity in BV. In our opinion, in dysbiosis there is an escape of opportunistic pathogens (first, anaerobic) from the control of the immune system, which causes BV-associated immunodeficiency and the development of BV.

Earlier we showed $[8,9]$ that against the background of reduced TBM and LB content sharply increased NBI, detectability and number of opportunistic pathogens (especially anaerobes, which did not occur in the normocenosis - Sneathia spp. + Leptotrihia spp. + Fusobacterium spp.), as well as uncharacteristic for the normocenosis mycoplasmas. It is possible that these antigens activated the response of the immune system, which in the process of developing BV evolved from nonspecific resistance to cytokine-induced reactions of specific humoral immunity. This explains the negative relationship of NBI with the content in the vaginal discharge of the activator of the immune system - y-INF and the level in the blood of the CIC in grade II dysbiosis.

On the other hand, it also explains the positive relationship with the $\mathrm{NBI}$ content in the vaginal discharge of the complement component $\mathrm{C}_{4}$. Regarding the positive relationship of TNFa in the blood with $\mathrm{NBI}$, it should be noted that according to [4] the growth of BV-associated microflora corresponds to the activation of cytokine cascades in vivo, and according to [13] in vitro studies showed that proinflammatory cytokines in high concentrations characteristic of BV, stimulate the growth of opportunistic pathogens. Thus, we can assume that in the process of BV development, proinflammatory cytokines are transformed from factors that inhibit the growth of pathogenic microflora into factors that activate it.

Discussing the results presented in table 2, we can establish that the correspondence of shifts in the content of complement $\mathrm{C}_{4}$ in vaginal discharge and $\mathrm{CIC}$ in the blood indicates a single mechanism of involvement of these parts of the immune system in dysbiosis, and mathematical proof of this connection in neural network analysis indicates the possibility of the content of $\mathrm{CIC}$ in the blood as a prognostic factor of stress of the humoral part of the immune system in grade I dysbiosis and its depletion in grade II dysbiosis and BV.

In our study, all studied proinflammatory cytokines (IL1ß, IL6, IL8, TNF $\alpha$ and IL2) had a similar response - a clear increase according to the degree of bacterial dysbiosis with a maximum at BV: $3.0-6.0$ times $(p<0.001)$ in comparable for the level of the normocenosis. The leading position in this list of TNFa confirms its role as an immediate factor that regulates immune inflammation the cytokine of "first stage" [5]. Other interleukins help to prolong and expand inflammation and recruit immunocompetent cells into the focus, involving the endocrine and other body systems in inflammation.

The prospect of further development is to implement the developed neural network model in health care practice and conduct an expert evaluation of the effectiveness of the proposed method for predicting the severity of vaginal bacterial dysbiosis according to indicator of normobiota.

\section{Conclusions}

1. By neural network modeling, it was found that among all the factor signs for determining the degree of bacterial dysbiosis were important content in the vaginal discharge: 
complement component $\mathrm{C} 4$ and $\mathrm{y}$-INF; in the blood - CIC and TNFa. A dedicated set factor variable was constructed linear neural network model (Cohen kappa index for the training set was $\kappa=0.87(0.82-0.91 \mathrm{Cl} 95 \%)$, to supporting the set $-\kappa=0.89(95 \% \mathrm{Cl} 0.77-1.00)$.

2. Complement activation, increased content of $\mathrm{Y}$-INF and TNFa reduced the rate of normobiota in the normocenosis. The increase in the content of $\mathrm{CIC}$ in the blood corresponded to the growth of opportunistic pathogenic microflora and reflected the activation of the humoral immune response, which gave reason to consider this indicator as an early marker of dysbiosis.

\section{References}

[1] Bautista, C. T., Wurapa, E., Sateren, W. B., Morris, S., Hollingsworth, B., \& Sanchez, J. L. (2016). Bacterial vaginosis: a synthesis of the literature on etiology, prevalence, risk factors, and relationship with chlamydia and gonorrhea infections. Mil. Med. Res., 13, 3, 4. doi: 10.1186/s40779-0160074-5.

[2] Brusselaers, N., Shrestha, S., van de Wijgert, J., \& Verstraelen, H. (2019). Vaginal dysbiosis and the risk of human papillomavirus and cervical cancer: systematic review and meta-analysis. Am. J. Obstet. Gynecol., 221(1), 9-18. doi: 10.1016/j.ajog.2018.12.011.

[3] Coudray, M. S., \& Madhivanan, P. (2020). Bacterial vaginosis A brief synopsis of the literature. Eur. J. Obstet. Gynecol. Reprod. Biol., 245, 143-148. doi: 10.1016/j.ejogrb.2019.12.035.

[4] Cox, C., Watt, A. P., McKenna, J. P., \& Coyle, P. V. (2016). Mycoplasma hominis and Gardnerella vaginalis display a significant synergistic relationship in bacterial vaginosis. Eur. J. Clin. Microbiol. Infect. Dis., 35(3), 481-487. doi: 10.1007/ s10096-015-2564-X.

[5] Delves, P. J., Martin, S. J., Burton, D. R., \& Roitt, I. M. (2016). Roitt's Essential Immunology, 13th Edition. Wiley-Blackwell.

[6] Gruzevskiy, A. A. (2019). Colonization resistance of vaginal secretion. Journal of Education, Health and Sport, 9(2), 583595. http://dx.doi.org/10.5281/zenodo.39931.

[7] Gruzevskyy, O. A. (2018). Indicators of the hormonal regulation system of vaginal colonization resistance. Act. Probl. Transport. Med., 51(1), 84-90.

[8] Gruzevsky, O. A. (2017). Colonization resistance in vaginal dysbiosis: the state of the humoral and cellular links. Bulletin of Marine Medicine, 77(4), 103-107.

[9] Gruzevsky, O. A., \& Vladimirova, M. P. (2014). The results of a comprehensive bacteriological study of the contents of the vagina under conditions of bacterial vaginosis. Achievements in biology and medicine, 2, 54-57.

[10] Guryanov, V. G., Lyakh, Yu. Ye., Pariy, V. D., Korotky, O. V., Chaly, O. V., \& Chaly, K. O. (2018). Handbook of Biostatistics. Analysis of the results of medical research in the package EZR (R-statistics). Kyiv: News.

[11] Hickey, R. J., Zhou, X., Pierson, J. D., Ravel, J., \& Forney, L. J. (2012). Understanding vaginal microbiome complexity from an ecological perspective. Transl. Res., 160(4), 267-282. doi: 10.1016/j.trsl.2012.02.008.
3. In grade I dysbiosis, all factors had a positive relationship with the rate of normobiota, which, in our opinion, contributed to the uncontrolled growth of opportunistic pathogens (first, anaerobic) microflora and reflected the state of stress of the immune system. In grade II dysbiosis, NBI had a negative relationship with the content of $\mathrm{Y}$-INF in the vaginal discharge and the $\mathrm{CIC}$ in the blood, while it was positive for the content of $\mathrm{C}_{4}$ in the vaginal discharge and TNFa in the blood. Thus, under conditions of advanced vaginal dysbiosis, dysregulation of the immune system was formed, which could lead to its suppression and the development of BV-associated immunodeficiency.

[12] Kira, E. F. (2012). Bacterial vaginosis. Moscow: Medical Information Agency.

[13] Kremleva, E. A., \& Sgibnev, A. V. (2016). Proinflammatory cytokines as regulators of vaginal microbiota. Bull. Exp. Biol. Med., 162(1), 75-78. doi: 10.1007/s10517-016-3549-1.

[14] Lipova, E. V., Boldyreva, M. N., Trofimov, D. Yu., \& Vitvitskaya, Yu. G. (2015). Femoflor. Urogenital infection caused by opportunistic biota in women of reproductive age (clinical and laboratory diagnostics). A guide for doctors. Moscow: DNA technology.

[15] Masson, L., Barnabas, S., Deese, J., Lennard, K., Dabee, S., Gamieldien, H. ... Williamson, A. L. (2019). Inflammatory cytokine biomarkers of asymptomatic sexually transmitted infections and vaginal dysbiosis: a multicentre validation study. Sex Transm. Infect., 95(1), 5-12. doi: 10.1136/sextrans-2017053506.

[16] McKinnon, L. R., Achilles, S. L., Bradshaw, C. S., Burgener, A., Crucitti, T., Fredricks, D. N. ... Kaul, R. (2019). The evolving facets of bacterial vaginosis: implications for HIV transmission. AIDS Res. Hum. Retroviruses., 35(3), 219-228. doi: 10.1089/ AID.2018.0304

[17] Muzny, C. A., \& Schwebke, J. R. (2016). Pathogenesis of bacterial vaginosis: discussion of current hypotheses. $J$. Infect. Dis., 15, 214, 1, 1-5. doi: 10.1093/infdis/jiw121.

[18] Muzny, C. A., Taylor, C. M., Swords, W. E., Tamhane, A., Chattopadhyay, D., Cerca, N., \& Schwebke, J. R. (2019). An updated conceptual model on the pathogenesis of bacterial vaginosis. J. Infect. Dis., 220(9), 1399-1405. doi: 10.1093/ infdis/jiz342.

[19] Nasioudis, D., Linhares, I. M., Ledger, W. J., \& Witkin, S. S. (2017). Bacterial vaginosis: a critical analysis of current knowledge. BJOG. 124(1), 61-69. doi: 10.1111/14710528.14209.

[20] Titz, N. W. (1997). Encyclopedia of Clinical Laboratory Tests. Moscow: Labinform.

[21] van de Wijgert, J. H. M., \& Jespers, V. (2017). The global health impact of vaginal dysbiosis. Res. Microbiol., 168(9-10), 859864. doi: 10.1016/j.resmic.2017.02.003.

[22] Ventolini, G. (2016). Progresses in vaginal microflora physiology and implications for bacterial vaginosis and candidiasis. Womens Health (Lond), 12(3), 283-291. doi: 10.2217/ whe.16.5.

\section{МОДЕЛЬ ПРОГНОЗУВАННЯ СТУПЕНЯ ТЯЖКОСТІ ВАГІНАЛЬНОГО БАКТЕРІАЛЬНОГО ДИСБІОЗУ ЗА ПОКАЗНИКОМ НОРМОБІОТИ}

Грузевський О.А., Мінухін В.В.

Основним механізмом розвитку вагінального бактеріального дисбіозу та його крайнього прояву - бактеріального вагінозу (БВ) - $є$ локальний та системний імунодефріцит. Актуальним $є$ вивчення комплексної імунної відповіді та встановлення 
основних механізмів та чинників, що ї̈ відображають та відповідають тяжкості порушення мікробіоценозу. Мета дослідження - розробити нейромережеву модель ступеня тяжкості вагінального бактеріального дисбіозу на підставі оцінки показнику нормобіоти. Були використані дані 298 жінок, які за індексом умовно патогенної мікрофрлори (ІУПМ) та показником нормобіоти (ПНБ) були розподілені на групи: нормоценоз (n=53), дисбіоз I (n=128) і II ступеня (n=117); серед останніх виокремлено 83 пацієнтки з ПНБ>1 lg ГЕ/зразок, в яких був встановлений БВ. Молекулярно-генетичні дослідження зіскрібка епітелію з задньобокової стінки піхви проводили методом полімеразної ланцюгової реакції ("ДНК-технологія", РФ). Кількісно визначали фракультативні і облігатні анаероби, міко- і уреплазми та дріжджоподібні гриби. У крові та вагінальному секреті визначали вміст імуноглобулінів, лізоциму, цитокінів, комплементу, активність фагоцитозу лейкоцитів, гормонів, кількості лімфоцитів та їх фракцій, а також рН вагінального секрету (загалом - 58 показників). Для статистичного та математичного аналізу використовували програму Statistica 10 (StatSoft, Inc., USA). Шляхом нейромережевого моделювання було з'ясовано, що серед усіх фракторних ознак для визначення ступеня бактеріального дисбіозу мали значення вміст у вагінальному секреті компоненту комплементу C4 і y-INF, а у крові - циркулюючих імунних комплексів (ЦІК) і TNFа. На виділеному наборі фракторних ознак була побудована лінійна нейромережева модель (показник згоди каппа Коена на навчальній множині склав к=0,87 (95\% BI 0,82-0,91)), на підтверджувальній множині - к=0,89 (95\% BI 0,77-1,00). Активація комплемента, підвищення вмісту ү-INF ma TNFa знижували показник нормобіоти при нормоценозі. Підвищення у крові вмісту ЦІК відповідало росту умовно патогенної мікрофрлори та відображало активацію гуморальної імунної відповіді, що дає підставу вважати цей показник раннім маркером дисбіозу. При дисбіозі І ступеня всі чинники мали позитивні зв'язки з ПНБ, що відображало стан напруження імунної системи. При дисбіозі II ступеня ПНБ мав від'ємний зв'язок з вмістом у вагінальному секреті ү-INF, а у крові - ЦІК, тоді як позитивний - з вмістом у вагінальному секреті $C_{4}$, а у крові - TNFa, що свідчило про дизрегуляцію імунної системи та обумовлювало ї подальшу супресію з розвитком БВ-асоційованого імунодефіциту. Реакція імунної системи у процесі розвитку БВ еволюціонувала від реакцій неспецифічної резистентності до індукованих цитокінами реакцій специфічного гуморального імунітету у відповідь на зріст БВ-асоційованої мікробіоти, що згодом зазнавало виснаження та втрату імунного контролю. Ключові слова: бактеріальний вагіноз, показник нормобіоти, імунна система.

\section{МОДЕЛЬ ПРОГНОЗИРОВАНИЯ СТЕПЕНИ ТЯЖЕСТИ ВАГИНАЛЬНОГО БАКТЕРИАЛЬНОГО ДИСБИОЗА ПО ПОКАЗАТЕЛЯМ НОРМОБИОТЫ \\ Грузевский А.А., Минухин В.В.}

Основным механизмом развития вагинального бактериального дисбиоза и его крайнего проявления - бактериального вагиноза (БВ) - является локальный и системный иммунодефицит. Актуальным является изучение комплексного иммунного ответа и установление основных механизмов и фракторов, отражающих его и соответствующих тяжести нарушения микробиоценоза. Цель исследования - разработать нейросетевую модель степени тяжести вагинального бактериального дисбиоза на основании оценки показателя нормобиоты. Были использованы данные 298 женщин, которые по индексу условнопатогенной микрофрлоры (ИУПМ) и показателям нормобиоты (ПНБ) были распределены на группы: нормоценоз (n=53), дисбиоз I (n=128) и II степени (n=117); среди последних были выделены 83 пациентки с ПНБ>1 lg ГЭ/образец, у которых был установлен БВ. Молекулярно-генетические исследования соскоба эпителия с заднебоковой стенки влагалища проводили методом полимеразной цепной реакции ("ДНК-технология", РФ). Количественно определяли фракультативные и облигатные анаэробы, мико- и уреплазмы и дрожжеподобные грибы. В крови и вагинальном секрете определяли содержание иммуноглобулинов, лизоцима, цитокинов, комплемента, активность фрагоцитоза лейкоцитов, гормонов, количества лимфоцитов и их фракций, а также рН вагинального секрета (всего 58 показателей). Для статистического и математического анализа использовали программу Statistica 10 (StatSoft, Inc., USA). Путем нейросетевого моделирования было установлено, что среди всех фракторных признаков для определения степени бактериального дисбиоза имели значение содержание в вагинальном секрете компонента комплемента C4 и ү-INF, а в крови - циркулирующих иммунных комплексов (ЦИК) и TNFa. На выделенном наборе фракторных признаков была построена линейная нейросетевая модель (показатель согласия каппа Коэна на обучающем множестве составил к=0,87 (95\% ВИ 0,82-0,91)), на подтверждающем множестве $\kappa=0,89$ (95\% ВИ 0,77-1,00). При нормоценозе снижали ПНБ активация комплемента, повышение содержания $\gamma$-INF и TNFa. Повышение в крови содержания ЦИК соответствовало росту условнопатогенной микрофрлоры и отражало активацию гуморального иммунного ответа, что дает основание считать этот показатель ранним маркером дисбиоза. При дисбиозе I степени все фракторы имели положительные связи с ПНБ, что отражало состояние напряжения иммунной системы. При дисбиозе II степени ПНБ имел отрицательную связь с содержанием в вагинальном секрете $\gamma$-INF, а в крови - ЦИК, тогда как положительный - с содержанием в вагинальном секрете $C_{4}$, а в крови - TNFa, что свидетельствовало о дисрегуляции иммунной системы и обусловливало ее дальнейшую супрессию с развитием БВ-ассоциированного иммунодефицита. Реакция иммунной системы в процессе развития БВ эволюционировала от реакций неспецифической резистентности до индуцированных цитокинами реакций специфического гуморального иммунитета в ответ на рост БВ-ассоциированной микробиоты, что впоследствии приводило к истощению и потери иммунного контроля.

Ключевые слова: бактериальный вагиноз, показатель нормобиоты, иммунная система. 